\title{
PENGARUH MODEL GIVING QUESTION GETTING ANSWERS MELALUI METODE EKSPERIMEN TERHADAP MOTIVASI DAN HASIL BELAJAR FISIKA
}

\author{
Farizah Yulianti1), Sutrio1), Hairunisyah Sahidu1) \\ ${ }^{1)}$ Program Studi Pendidikan Fisika, FKIP, Universitas Mataram, Mataram, Indonesia \\ Corresponding author : Farizah Yulianti \\ E-mail : farizahyulianti22@gmail.com
}

Diterima 28 Desember 2019, Disetujui 2 April 2020

\begin{abstract}
ABSTRAK
Penelitian ini bertujuan untuk mengetahui pengaruh penerapan model Giving Question Getting Answers melalui metode eksperimen terhadap motivasi dan hasil belajar fisika peserta didik. Jenis penelitian yang digunakan adalah quasi eksperimen dengan posstest only control group disign. Populasi terdiri dari seluruh peserta didik kelas XI SMAN 1 Labuapi. Teknik pengambilan sample yang digunakan adalah sampling jenuh, dengan kelas XI MIA 1 sebagai kelas eksperimen 1 dan kelas XI MIA 2 sebagai kelas eksperimen 2. Kelas eksperimen 1 diberi perlakuan model Giving Question Getting Answers melalui metode eksperimen sedangkan kelas eksperimen 2 diberi perlakuan menggunakan model pembelajaran Giving Question Gettig Answers tanpa metode eksperimen. Instrumen motivasi belajar menggunakan angket motivasi sedangkan instrumen hasil belajar menggunakan soal pilihan ganda. Hipotesis penelitian diuji menggunakan uji Manova, hasilnya menunjukkan Nilai Sig. $<0,05$ maka $\mathrm{H}_{0}$ ditolak dan $\mathrm{H}_{\mathrm{a}}$ diterima sehingga dapat disimpulkan bahwa terdapat pengaruh model Giving Question Getting Answers melalui metode eksperimen terhadap motivasi dan hasil belajar fisika peserta didik.
\end{abstract}

Kata kunci: model GQGA melalui metode eksperimen; motivasi; hasil belajar.

\section{ABSTRACT}

The aim of this research is to know the impact of the applying Giving Question Getting Answers model with experimental methods toward the learning motivation and result of physics learning. The type of research used was quasi-experimental with posttest only control group design. The population was all student of grade XI in senior high school 1 of Labuapi. The sampling technique used saturation sampling, while the sample are class XI MIA 1 as the experimental 1 class, and the XI MIA 2 as experimental 2 class. Experimental 1 class was treated with giving question getting answers learning model with experimental methods and experimental 2 class was treated with giving question getting answers learning model without experimental methods. The instrument of motivation learning was used motivation questionnaire and instrument the result of physics learning used multiple choice test. The research hypothesis was tested using Manova-test, data analysis shows that Sig. $<0,05$ which mean that $\mathrm{H}_{0}$ was rejected and $\mathrm{H}_{\mathrm{a}}$ accepted. Thus, it can be concluded that there are effect of Giving Question Getting Answers model with experimental methods on student's motivation and physics learning result.

Keywords: GAGQ model with experimental methods; motivation; physics learning result.

\section{PENDAHULUAN}

Fisika merupakan bagian dari IPA yang mempelajari gejala-gejala alam dan interaksi di dalamnya melalui serangkaian proses ilmiah. Pembelajaran fisika hendaknya tidak hanya menanamkan pengetahuan sebagai produk saja tetapi juga sebagai proses dan sikap yang mengaplikasikan materi pembelajaran dalam kehidupan sehari-hari karena menurut Utami (2014) fisika mempelajari tentang fenomena alam pada tingkat dasar, logikanya sangat masuk akal karena sesuai dengan pengalaman kita sehari-hari. Oleh karena itu dalam belajar fisika diharapkan peserta didik tidak hanya menghafal teori namun dapat memahami fenomena dan menyelesaikan permasalahan yang berhubungan dengan kehidupan seharihari.

Secara ideal, pembelajaran fisika akan lebih menarik dan menyenangkan apabila guru mampu menyajikan proses pembelajaran sesuai tuntutan kurikulum pendidikan yaitu menyelenggarakan pembelajaran secara aktif, interaktif, inspiratif, menyenangkan, menantang, serta memotivasi peserta didik terlibat aktif dalam proses pembelajaran. Hikmawati (2015) menyatakan bahwa guru semestinya membantu peserta didik untuk aktif dalam mencari konsep, prinsip, dan fakta bagi diri mereka sendiri, bukan hanya memberikan 
ceramah dan mengendalikan kelas (teacher centered). Dengan demikian, peserta didik akan mampu untuk membangun pengetahuannya sendiri. Hal tersebut dapat dicapai apabila guru dapat menerapkan model dan metode pembelajaran yang tepat karena pembelajaran yang monoton akan membuat peserta didik kurang termotivasi untuk belajar.

Kondisi pembelajaran fisika di kelas yang terjadi belakangan ini lebih banyak menempatkan peserta didik sebagai objek yang dapat menerima dan mendengar saja. Guru lebih banyak berperan sebagai informan bagi peserta didik, materi-materi yang dirasa penting dicatatkan oleh guru di papan tulis sementara peserta didik cenderung pasif, proses pembelajaran fisika masih bergantung pada guru dan buku paket sehingga pembelajaran yang seharusnya berbasis student centred menurut tuntutan kurikulum 2013 tidak terlaksana. Hal ini sesuai dengan yang diungkap oleh Lilawati (2011) bahwa pembelajaran fisika masih didominasi oleh pembelajaran yang bersifat teacher-oriented dan peserta didik kurang diberi kesempatan untuk mengembangkan kemampuan berpikir sehingga kegiatan pembelajaran masih kurang memfasilitasi peserta didik untuk terlibat aktif dalam proses pembelajaran. Patut diduga hal ini mengakibatkan pembelajaran fisika menjadi kurang menarik, monoton, membosankan dan dianggap sebagai pelajaran yang sulit sehingga motivasi peserta didik dan hasil belajar fisika menjadi rendah. Fenomena yang sama juga dinyatakan oleh Pelawi dan karya (2016) berdasarkan hasil observasi yang dilakukan di SMA Swasta Sinar Husni didapatkan fakta bahwa pembelajaran fisika masih berorientasi pada guru. Peserta didik cendrung menerima apa saja yang dijelaskan oleh guru tanpa harus mengetahui makna dari pelajaran tersebut, peserta didik cendrung mengahafal pengertian dan rumus, hal ini menyebabkan peserta didik pasif, kurang termotivasi dalam belajar, dan menganggap fisika itu sulit dan membosankan sehingga peserta didik mengalami kesulitan belajar dan menyebabkan hasil belajar fisika menjadi rendah.

Permasalahan tersebut perlu diupayakan, salah satu caranya dengan menggunakan model pembelajaran yang lebih interaktif dan menarik. Salah satu alternatif model pembelajaran yang dapat digunakan adalah model giving questions getting answers. Hal ini, sesuai dengan penelitian yang dilakukan oleh Chasanah et al,. (2012) yang menyatakan bahwa penerapan model pembelajaran giving questions getting answer memberikan pengaruh positif terhadap hasil belajar karena model pembelajaran ini mendorong peserta didik lebih aktif, lebih berani menyampaikan pertanyaan dan pendapatnya serta membantu peserta didik lebih memahami materi yang diajarkan, berdasarkan hasil penelitian didapatkan bahwa pemahaman peserta didik yang mengikuti pembelajaran giving question gettinng answer lebih baik daripada peserta didik yang megikuti pembelajaran konvensional. Yunus dan Kurniati (2013) menyatakan model giving questions getting answer memberikan kesempatan kepada peserta didik untuk mengemukakan pokok pikirannya sendiri kepada temantemannya dan berdiskusi mengenai konsep yang belum dimengerti dalam pelajaran. Dengan demikian model pembelajaran ini akan menghidupkan kelas dengan suasana belajar yang menyenangkan serta meningkatkan partisipasi belajar peserta didik.

Suprijono (2012) mengungkapkan model pembelajaran giving question getting answers juga dikembangkan untuk melatih peserta didik memiliki kemampuan dan keterampilan bertanya dan menjawab pertanyaan. Hal tersebut sangat menunjang proses pembelajaran karena kegiatan bertanya dan menjawab merupakan hal yang sangat esensial dalam pola interaksi antara guru dan siswa yang mampu menumbuhkan pengetahuan baru dan menambah pemahaman peserta didik dalam belajar fisika. Keuntungan dari model pembelajaran giving question getting answers adalah peserta didik mendapat kesempatan baik secara individu maupun kelompok untuk menanyakan hal-hal yang belum dimengerti, guru juga dapat mengetahui penguasaan peserta didik terhadap materi yang disampaikan, mendorong keberanian peserta didik untuk mengajukan pendapatnya serta dapat menumbuhkan sikap saling menghargai antar peserta didik (Yunus dan Kurniati, 2013)

Mengingat fisika sebagai sains dipandang sebagai proses, produk, dan sikap ilmiah maka pembelajaran fisika dapat menjadi lebih menarik jika dalam pelaksanaannya guru menerapkan metode yang membuat peserta didik terlibat secara aktif. Salah satu contohnya adalah dengan menerapkan metode eksperimen (Ardhuha et al., 2013). Metode eksperimen ialah suatu cara penyajian mata pelajaran dimana siswa secara aktif mengalami dan membuktikan sendiri apa yang sedang dipelajarinya. Melalui metode ini siswa secara total dilibatkan dalam melakukan sendiri, membuktikan dan menarik kesimpulan sendiri tentang suatu objek, keadaan atau proses tertentu (Djamarah \& Zain, 2010). Melalui metode eksperimen peserta didik dapat belajar secara langsung dari interaksi dengan benda- 
benda yang digunakan dalam kegiatan tersebut (Widiyanto, 2011).

Pembelajaran IPA dengan pengamatan langsung terhadap gejala-gejala atau prosesproses sains, dapat melatih kemampuan berpikir ilmiah, dapat menanamkan dan mengembangkan sikap ilmiah, dapat menemukan dan memecahkan berbagai masalah baru melalui metode ilmiah dan lain sebagainya (Astuti et al., 2012). Fungsi dari eksperimen itu sendiri adalah sebagai penunjang pembelajaran guna meningkatkan pemahaman peserta didik terhadap materi yang telah dipelajari (Salam et al., 2010). Kelebihan metode eksperimen menurut Mayangsari et al., (2014) adalah membangkitkan rasa ingin tahu; membangkitkan sikap ilmiah; membuat pembelajaran bersifat aktual; membina kebiasaan belajar kelompok maupun individu. Oleh karena itu penerapan model giving question getting answers melalui metode eksperimen akan membuat proses pembelajaran berlangsung lebih optimal sehingga dapat meningkatkan motivasi belajar dan hasil belajar peserta didik.

\section{METODE PENELITIAN}

Jenis penelitian yang digunakan adalah kuasi eksperimen. Dalam kuasi eksperimen, peneliti tidak selalu dapat melakukan pemilihan subjek secara random akan tetapi peneliti terpaksa harus menerima subjek yang telah dikelompokkan dalam suatu kelas yang ditentukan berdasarkan kebijakan sekolah (Setyosari, 2016). Desain penelitian yang digunakan adalah posttest only control group. Desain penelitian ini menggunakan dua kelompok subjek yaitu kelas eksperimen 1 dan kelas eksperimen 2. Tidak ada pretest yang diberikan kepada kedua kelompok (Setyosari, 2016). Desain penelitian ini dapat dilihat dalam Tabel 1.

Tabel 1. Desain Penelitian Posttest Only Control Group Design

\begin{tabular}{llll}
\hline & Kelompok & Perlakuan & $\begin{array}{l}\text { Post- } \\
\text { test }\end{array}$ \\
\hline 1 & Eksperimen & $\mathrm{X}_{1}$ & $\mathrm{O}_{1}$ \\
\hline 2 & Eksperimen & $\mathrm{X}_{2}$ & $\mathrm{O}_{2}$ \\
\hline & & & (Setyosari,
\end{tabular}

2016)

Keterangan :

$\mathrm{O}_{1}=$ Kelas eksperimen 1

$\mathrm{O}_{2}=$ Kelas eksperimen 2.

$\mathrm{X}_{1}=$ Perlakuan berupa model pembelajaran giving question getting answer melalui metode eksperimen

\section{$\mathrm{X}_{2}=$ Perlakuan berupa model pembelajaran giving question getting answer}

Populasi dalam penelitian adalah semua peserta didik kelas XI MIA tahun pelajaran 2019/2020 sebanyak 44 peserta didik yang terbagi dalam kedua kelas. Teknik pengambilan sampel menggunakan sampling jenuh karena seluruh populasi digunakan sebagai sampel sehingga terpilihlah kelas $\mathrm{XI}$ MIA 1 sebagai kelas eksperimen 1 dan kelas $X I$ MIA 2 sebagai kelas eksperimen 2. Motivasi belajar peserta didik diukur menggunakan instrumen non tes berupa angket motivasi belajar sebanyak 25 pernyataan sedangkan hasil belajar fisika peserta didik diukur dengan instrumen tes berupa soal pilihan ganda sebanyak 25 pertanyaan.

Instrumen angket dilakukan uji validitas ahli sedangkan instrumen tes diuji dengan uji validitas butir soal, uji reliabilitas, uji tingkat kesukaran soal, uji daya beda soal dan penyebaran pilihan jawaban. Hasil analisis validitasi item soal dapat dilihat pada tabel 2 berikut.

Tabel 2. Hasil Analisis Validitas Item Soal Pilihan Ganda

\begin{tabular}{ccc}
\hline Kategori & $\begin{array}{c}\text { Jumlah } \\
\text { Item }\end{array}$ & Keterangan \\
\hline Valid & 26 & $\mathrm{r}_{\mathrm{XY}} \geq \mathrm{r}_{\text {tabel }}$, \\
Tidak Valid & 4 & $r_{X Y}<\mathrm{r}_{\text {tabel }}$, \\
\hline Uji validitas & menyatakan bahwa dari 30
\end{tabular}

butir soal yang tersedia terdapat 26 soal yang valid, selanjutnya peneliti menggunakan 25 soal untuk penelitian dengan pertimbangan waktu dan keluasan materi.

Hasil analisis reliabilitas item soal pilihan ganda dapat dilihat pada Tabel 3.3

Tabel 3 Hasil Analisis Reliabilitas Item Soal

\begin{tabular}{ccc}
\hline $\mathbf{r}_{\mathbf{1 1}}$ & $\mathbf{r}_{\text {tabel }}$ & Kriteria \\
\hline 0,876 & 0,361 & Reliabel \\
\hline
\end{tabular}

Nilai reliabilitas untuk keseluruhan item soal $\left(r_{11}\right)$ setelah dilakukan perhitungan yaitu sebesar 0,876 sedangkan nilai $r_{\text {tabel }}$ untuk $\mathrm{N}=$ 30 pada taraf signifikan $5 \%$ yaitu 0,361 . Berdasarkan perhitungan dan analisis disimpulkan bahwa $r_{11}>r_{\text {tabel }}$, maka instrumen tes penelitian termasuk dalam kriteria reliabel.

Hasil Analisis Tingkat Kesukaran Soal Pilihan Ganda dapat di; ihat pada tabel 4 berikut.

Tabel 4 Hasil Analisis Tingkat Kesukaran Soal Pilihan Ganda

\begin{tabular}{ccc}
\hline Kategori & $\begin{array}{c}\text { Jumlah } \\
\text { Item }\end{array}$ & Rentang Nilai \\
\hline Mudah & 5 & $0,00-0,30$
\end{tabular}




\begin{tabular}{cll} 
Sedang & 15 & $0,31-0,70$ \\
Sukar & 10 & $0,71-1,00$ \\
\hline
\end{tabular}

Hasil perhitungan dan analisis daya pembeda instrumen tes pada penelitian ini disajikan pada Tabel 5 berikut.

Tabel 5 Hasil Analisis Daya Beda Item Soal Pilihan Ganda

\begin{tabular}{lcc}
\hline Kategori & $\begin{array}{c}\text { Jumlah } \\
\text { Item }\end{array}$ & $\begin{array}{c}\text { Rentang } \\
\text { Nilai }\end{array}$ \\
\hline Jelek & 4 & $0,00-0,20$ \\
Cukup & 15 & $0,21-0,40$ \\
Baik & 11 & $0,41-0,70$ \\
Baik sekali & - & $0,71-1,00$ \\
\hline
\end{tabular}

Daya pembeda instrumen tes dalam penelitian ini terdapat 3 kategori yaitu daya pembeda dengan kategori baik sebanyak 11 item soal, kategori cukup sebanyak 15 item soal dan kategori jelek sebanyak 4 item soal

Hasil perhitungan dan analisis penyebaran jawaban instrumen tes pada penelitian ini disajikan pada Tabel 6 berikut.

Tabel 6. Hasil Perhitungan Penyebaran Pilihan Jawaban

\begin{tabular}{ccc}
\hline $\begin{array}{c}\text { Penyebaran } \\
\text { Jawaban }\end{array}$ & $\begin{array}{c}\text { Jumlah } \\
\text { Item Soal }\end{array}$ & Kriteria \\
&
\end{tabular}

$\begin{array}{lll}\geq 0,025 & 30 \quad \begin{array}{l}\text { Semua } \\ \text { Pengecoh } \\ \text { Berfungsi }\end{array}\end{array}$

Pengecoh A, B, C, D dan E pada instrumen tes memiliki nilai $\geq 0,025$ yang berarti semua pengecoh berfungsi.

Prasyarat analisis data terdiri dari 2 uji yaitu uji normalitas menggunakan uji Chi Kuadrat dan uji hipotesis menggunakan uji $\mathrm{F}$. Sugiyono (2017) merumuskan uji Chi Kuadrat sebagai berikut.

$$
\chi_{\mathrm{h}}{ }^{2}=\frac{\left(\mathrm{f}_{\mathrm{o}}-\mathrm{f}_{\mathrm{h}}\right)^{2}}{\mathrm{f}_{\mathrm{h}}}
$$

Irianto (2014) merumuskan uji- $F$ sebagai berikut.

$$
\mathrm{F}(\max )=\frac{\text { variansi terbesar }}{\text { variansi terkecil }}
$$

Setelah dilakukan uji prasayarat, maka dilakukan analisis uji hipotesis menggunakan uji Manova. Uji hipotesis dilakukan untuk mengetahui perbedaan motivasi belajar dan hasil belajar fisika peserta didik pada kedua kelas setelah diberi perlakuan.

\section{HASIL DAN PEMBAHASAN}

Tujuan penelitian ini untuk mengetahui pengaruh model pembelajaran giving question getting answers melalui metode eksperimen terhadap motivasi dan hasil belajar fisika peserta didik. Data penelitian berupa data motivasi dan data hasil belajar yang didapat dari nilai posttest.

\section{Motivasi Belajar}

Data motivasi belajar dari kedua kelas disajikan pada tabel berikut.

Tabel 7. Nilai Motivasi Belajar Peserta Didik

$\begin{array}{cccc}\text { Kelas } & \text { Nilai } & \text { Nilai } & \text { Nilai } \\ & \text { Terendah } & \text { Tertinggi } & \text { Rata }\end{array}$

\begin{tabular}{cccc} 
& & & Rata \\
\hline $\begin{array}{c}\text { Eksperimen } \\
1\end{array}$ & 63 & 85 & 74 \\
$\begin{array}{c}\text { Eksperimen } \\
2\end{array}$ & 57 & 82 & 67 \\
\hline \multicolumn{2}{c}{ Data motivasi } & belajar peserta didik
\end{tabular}
memperlihatkan bahwa bahwa terdapat perbedaan nilai diantara kedua kelas. Kelas eksperimen 1 yang menerapkan model giving question getting answers melalui metode eksperimen mendapat nilai lebih tinggi daripada nilai peserta didik di kelas eksperimen 2 yang menerapkan model giving question getting answers tanpa metode eksperimen. Hal ini disebabkan metode eksperimen membuat peserta didik dapat belajar dengan lebih aktif dan bersemangat belajar karena peserta didik difasilitasi untuk melakukan kegiatan eksperimen guna membuktikan secara langsung teori yang telah dipelajari. Hal ini sejalan dengan pernyataan (Chebii et al, 2012) yang mengungkapkan bahwa peserta didik dapat belajar sains dengan baik ketika metode pengajaran memungkinkan mereka untuk terlibat secara aktif dalam kegiatan kelas dengan melakukan eksperimen, melakukan demonstrasi, diskusi kelas dan pengalaman belajar lain yang relevan.

Adanya kegiatan eksperimen yang dikolaborasikan dengan model giving question getting answers ini melatih kerjasama antar peserta didik dalam berinteraksi dan berdiskusi dengan teman kelompoknya sehingga membantu peserta didik terlibat aktif bertanya dan menjawab dalam proses pembelajaran. Hal ini selaras dengan pernyataan Suprijono (2015) bahwa model pembelajaran giving quetion getting answers dapat melatih kemampuan peserta didik untuk bertanya dan menjawab peranyaan. Pada kelas eksperimen 1 yang dipadukan dengan metode eksperimen 
membuat peserta didik lebih tertarik dan merasa tertantang untuk mengikuti kegiatan pembelajaran, sehingga bukan hanya aktif bertanya dan menjawab, mereka juga antusis dan semangat dalam melakukan prosedur ilmiah, mengambil data dan mengisi lembar kerja yang telah dibagikan. Hasil penelitian Widodo et al., (2013) menyatakan bahwa peserta didik yang mendapat pelajaran dengan bantuan eksperimen memiliki motivasi belajar yang tinggi sehingga berdampak pada hasil belajarnya yang meningkat.

Penerapan model pembelajaran giving question getting answers melalui metode eksperimen ini membuat setiap kelompok berlomba-lomba mengeksplorasi hasil pemikiran dan temuannya mengenai konsep yang dipelajari kemudian menyiapkan pertanyaan terkait apa yang belum dipahami.

Adanya kegiatan eksperimen membuat peserta didik lebih aktif, tidak hanya pada saat melakukan percobaan tetapi terlihat saat kegiatan diskusi kelas menggunakan kartu pertanyaan dan kartu jawaban berlangsung, dimana peserta didik antusias untuk mengajukan dan menjawab pertanyaan. Hal ini selaras dengan pernyataan Susanti, et al (2017) bahwa melalui penerapan model giving question getting answers peserta didik mendapat informasi berupa pertanyaan ataupun jawaban dari teman sekelas sehingga mereka termotivasi untuk mendukung dan menunjukkan minat terhadap materi yang dipelajari. Wenna (2008) juga menyatakan bahwa banyak ide dan gagasan yang mencul melalui penerapan model giving question getting answers. Inilah yang menjadikan peserta didik kelas eksperimen 1 memperoleh nilai motivasi yang lebih tinggi dibandingkan peserta didik kelas eksperimen 2. Nilai motivasi belajar peserta didik pada kelas eksperimen 1 juga lebih tinggi dari kelas eksperimen 2 dalam setiap indikator motivasi belajar yang digunakan. Datanya dapat dilihat pada tabel 8 berikut.

Tabel 8. Nilai Motivasi Belajar Tiap Indikator Motivasi Belajar

\begin{tabular}{clcc}
\hline No & Indikator & $\begin{array}{c}\text { Nilai Kelas } \\
\text { Eksperimen } \\
\mathbf{1}\end{array}$ & $\begin{array}{c}\text { Nilai Kelas } \\
\text { Eksperimen } \\
\mathbf{2}\end{array}$ \\
\hline 1 & $\begin{array}{l}\text { Adanya } \\
\text { hasrat dan } \\
\text { keinginan }\end{array}$ & 72 & 65 \\
& &
\end{tabular}

Adanya

dorongan

2 kebutuhan

72

65

dalam

belajar

Adanya

3 harapan dan

citacita masa

78

74

depan

Adanya

4 penghargaan

dalam

belajar

Adanya

kegiatan

5 yang

menarik

81

70

dalam

belajar

Adanya

6 lingkungan

kondusif

Data tersebut memperlihatkan bahwa

nilai tertinggi terdapat pada indikator kelima yang berbunyi adanya kegiatan menarik dalam belajar. Nilai tertinggi pada indikator tersebut menandakan bahwa model pembelajaran giving question getting answers melalui metode eksperimen yang menggunakan kartu pertanyaan dan kartu jawaban sebagai media pembelajaran kemudian dipadukan dengan kegiatan eksperimen merupakan kegiatan menarik minat peserta didik dalam belajar. Jika dicermati lebih jauh, terlihat bahwa perbedaan nilai paling besar antara kelas eksperimen 1 dan kelas eksperimen 2 juga terdapat pada indikator kelima, hal ini semakin memperkuat bukti bahwa memadukan metode eksperimen dengan model giving question getting answers merupakan kegiatan yang menarik dan mampu memenuhi kebutuhan peserta didik dalam belajar sehingga mampu menjadi pendorong dan penambah minat serta motivasi peserta didik dalam mengikuti pembelajaran fisika, hal ini sesuai dengan hasil penelitian (Pasa, 2016) yang menyatakan bahwa metode eksperimen mempengaruh motivasi belajar peserta didik. Meski nilai motivasi belajar peserta didik kelas ekperimen 1 lebih tinggi dari kelas eksperimen 2, tapi jika dilihat dari nilai rataratanya yang tidak jauh berbeda maka kedua kelas berada pada kategori yang sama yaitu memiliki motivasi yang tinggi karena menurut Arikunto (2012) rentang nilai motivasi belajar dari 65-79 termasuk dalam kategori yang tinggi. Hal tersebut dikarenakan model pembelajaran yang diterapkan pada kedua kelas sama yakni model pembelajaran giving question getting answers. Model pembelajaran ini 
menggunakan kartu pertanyaan dan kartu jawaban sebagai media pembelajaran yang dapat memicu keaktifan peserta didik dalam proses tanya jawab sehingga berpengaruh pada semangat dan motivasi belajar peserta didik sebagaimana hasil penelitian yang telah dilakukan oleh Wardani \& Supahar (2017) yang menyatakan bahwa pembelajaran aktif giving question getting answers mampu meningkatkan motivasi peserta didik.

\section{Hasil Belajar}

Data motivasi belajar pada kelas eksperimen 1 dan kelas eksperimen 2 disajikan pada tabel 9 berikut.

Tabel 9. Nilai Hasil Belajar Peserta Didik

\begin{tabular}{cccc} 
Kelas & $\begin{array}{c}\text { Nilai } \\
\text { Terendah }\end{array}$ & $\begin{array}{c}\text { Nilai } \\
\text { Tertinggi }\end{array}$ & $\begin{array}{c}\text { Nilai } \\
\text { Rata- } \\
\text { Rata }\end{array}$ \\
\hline $\begin{array}{c}\text { ksperimen } \\
1\end{array}$ & 60 & 96 & 82 \\
$\begin{array}{c}\text { ksperimen } \\
2\end{array}$ & 48 & 88 & 73 \\
\hline
\end{tabular}

Nilai motivasi belajar peserta didik pada kelas eksperimen yang lebih tinggi dari peserta didik di kelas kontrol juga berdampak pada hasil belajar peserta didik. Hal ini selaras dengan hasil penelitian Mappase (2009) yang menyatakan bahwa motivasi belajar peserta didik berpenaruh positif terhadap hasil belajar. Sardiman (2007) juga mengungkapkan adanya motivasi yang tepat akan mengoptimalkan hasil belajar. Dari hasil penelitian terlihat bahwa kedua kelas tersebut memiliki nilai yang cukup tinggi karena sudah mencapai bahkan melebihi Kriteria Ketuntasan Minimum (KKM) yang sebesar 73, berarti model pembelajaran yang diterapkan tidak hanya berpengaruh pada motivasi belajar tetapi juga berpengaruh pada hasil belajar, hal ini sesuai dengan penelitian Erdina (2017), Chasanah et al., (2012), dan Yunus \& Kurniati (2013) yang menyatakan bahwa dengan menerapkan pembelajaran aktif giving question getting answers dapat meningkatkan hasil belajar peserta didik.

Adanya kegiatan eksperimen, memudahkan guru dalam menyampaikan materi pelajaran karena peserta didik dapat melihat contoh langsung dari penjelasanpenjelasan yang dipaparkan sehingga peserta didik lebih mudah paham yang berdampak pada hasil belajar yang diperoleh. Hal ini juga selaras hasil penelitian Hamdu \& Agustina yang menyatakan bahwa motivasi belajar besar pengaruhnya terhadap prestasi belajar. Berbeda dengan proses pembelajaran di kelas eksperimen 1 yang memfasilitasi peserta didik untuk mencari tahu dan membuktikan secara langsung teori yang dipelajari melalui eksperimen/praktikum, pada kelas eksperimen 2 peserta didik hanya memperoleh pemahaman dari pemaparan guru dan kegiatan diskusi. Tidak adanya kegiatan eksperimen dalam proses pembelajaran ini berpengaruh terhadap pemahaman peserta didik, terlihat hasil belajar yang diperoleh lebih rendah dari kelas eksperimen 1.

Tahapan-tahapan pada proses pembelajaran menggunakan model pembelajaran giving question getting answers melalui metode eksperimen mendorong rasa ingin tahu peserta didik kemudian memberikan kesempatan untuk ikut aktif dalam kegiatan pembelajaran dengan tujuan meningkatkan motivasi belajar dan hasil belajar peserta didik. Menurut Handika (2010) metode eksperimen dapat membuat peserta didik lebih aktif dalam pembelajaran dan dapat membuktikan sendiri kebenaran suatu teori. Dalam proses pembelajaran dengan menerapkan model dan metode ini, peserta didik mengikuti kegiatan pembelajaran dengan aktif bahkan ketika diskusi kelas dibuka, masing-masing kelompok berlomba-lomba ingin menjadi kelompok yang aktif dengan terlibat dalam proses tanya jawab yang diadakan oleh guru. Hal ini membuktikan bahwa model pembelajaran giving question getting answers melalui metode eksperimen berpengaruh pada hasil belajar peserta didik, bukan hanya dalam ranah kognitif yang dilihat dari nilai posstest yang tinggi namun juga dilihat dari hasil belajar ranah afektif dan psikomotor peserta didik seperti kemampuan merangkai alat dan bahan praktikum, cara menyampaikan pendapat, keaktifan saat diskusi, keberanian untuk untuk bertanya, serta juga berpengaruh terhadap rasa percaya diri untuk menjawab pertanyaan.

Yatim (2009) mengungkapkan bahwa model pembelajaran giving question getting answers dapat meningkatkan keberanian peserta didik dalam mengungkapkan pendapatnya dan melatih sikap saling menghargai antar peserta didik karena memberikan kesempatan kepada peserta didik untuk bertanya mengenai hal yang tidak dimengerti dan memberikan kesempatan kepada peserta didik untuk menjelaskan hal yang sudah dimengerti kepada temannya yang lain. Pelaksanaan model pembelajaran giving question getting answers melalui metode eksperimen sangat berpengaruh positif karena dapat meningkatkan hasil belajar fisika peserta didik. Dengan kata lain, model pembelajaran giving question getting answers sangat cocok dipadukan dengan metode eksperimen. 


\section{SIMPULAN DAN SARAN}

Berdasarkan hasil penelitian dan pembahasan maka dapat ditarik simpulan bahwa terdapat pengaruh model pembelajaran giving question getting answers melalui metode eksperimen terhadap motivasi belajar dan hasil belajar fisika peserta didik SMAN 1 Labuapi. Pengaruh ini berupa tingkat motivasi dan hasil belajar fisika peserta didik di kelas eksperimen 1 lebih tinggi dibandingkan kelas eksperimen 2.

Saran untuk penelitian selanjutnya mengenai model pembelajaran giving question getting answers melalui metode eksperimen sebaiknya lebih memperhatikan alokasi waktu karena sesi diskusi menggunakan kartu pertanyaan dan kartu jawaban dalam model pembelajaran pembelajaran giving question getting answers akan memakan waktu yang cukup lama. Jika peneliti ingin menggunakan metode eksperimen, maka disesuaikan dengan karakteristik materi yang akan diajarkan.

\section{DAFTAR RUJUKAN}

Ardhuha, J., Wahyudi, \& Kosim. (2013). Pengembangan panduan praktikum fundamental of physics II sebagai bahan ajar untuk mendukung pelaksanaan praktikum pada program khusus PGMIPABI di FKIP Unram. Jurnal Kependidikan, 12(1), 37-41.

Arikunto, S. (2012). Prosedur Penelitian Suatu Pendekatan Praktek. Jakarta : Rineka Cipta.

Astuti, R., Widha, S., \& Suciati, S. (2012). Pembelajaran IPA dengan Pendekatan Keterampilan Proses Sains Menggunakan Metode Eksperimen Bebas Termodifikasi dan Eksperimen Terbimbing Ditinjau dari Sikap IImiah dan Motivasi Belajar Siswa. Jurnal Inkuiri. 1(1), 51-59.

Chasanah, A., Slamet, S., \& Arianto, J. (2012). Pengaruh Model Pembelajaran Aktif Tipe Giving Question and Getting Answers terhadap Hasil Belajar. Jurnal Pendidikan Biologi 4(3), 29-38.

Chebii, R., Wachanga, S., \& Kiboss, J. (2012). Effects of science process skills mastery learning approach on students' acquisition of selected chemistry practical skills in school. Creative Education. 3(1), 1291- 1296.

Djamarah, S. B., \& Zain, A. (2010). Strategi belajar mengajar. Jakarta: Rineka Cipta.

Erdina, E. (2017). Penerapan Pembelajaran GQGA untuk Meningkatkan Hasil Belajar Fisika. Jurnal Pendidikan
Sosial, Sains dan Humaniora. 3(4), 663-680.

Hamdu, H \& Agustina, A. (2011). Pengaruh Motivasi Belajar Siswa terhadap Prestasi Belajar IPA di Sekolah Dasar. Jurnal Penelitian Pendidikan. 12(1), 9096.

Handika, J. (2010). Pembelajaran Fisika melalui Inkuiri Terbimbing dengan Metode Eksperimen dan demonstrasi ditinjau dari aktivitas dan perhatian Mahasiswa. JP2F. 1(1), 9-23.

Hikmawati. (2015). Pembelajaran Fisika dengan Model Siklus Belajar 5 -E (Engage, Explore, Explain, Elaborate, Evaluate) Sebagai Upaya Meningkatkan Kecakapan Hidup Siswa. Jurnal Pendidikan Fisika dan Teknologi. 1(1), 27.

Irianto, A. (2014). Statistik. Jakarta: Kencana Prenada Media Group.

Liliawati, W. (2011). Pembekalan Keterampilan Berpikir Kreatif Siswa SMA melalui Pembelajaran Fisika Berbasis Masalah. Jurnal Pengajaran MIPA. 16(2), 93-98.

Mappase, M. (2009). Pengaruh Craa dan Motivasi Belajar terhadap Hasil Belajar Programmable Logic Controller (PLC) Siswa Kelas III Jurusan Listrik SMK Negeri 5 makasar. Jurnal MEDTEK. 1(2), 1-6.

Mayangsari, D., Nuriman., \& Agustiningsih. (2014). Penerapan Metode Eksperiment untuk Meningkatkan Ativitas dan Hasil Belajar IPA Siswa Kelas VI Pokok Bahasan konduktor dan Isolator SDN Semboro Probolinggo Tahun Pelajran 2012/2013. Jurnal Edukasi UNEJ. 1(1), 27-31.

Pasa, A I L. (2016). Penerapan Metode Eksperimen Terhadap Motivasi dan Hasil Belajar. Jurnal Ilmu Pendidikan Indonesia. 3(2), 173-186.

Pelawi, H S \& Karya, S. (2016). Pengaruh Model Problem ased Learning dan Motivasi Belajar terhadap Hasil Belajar Siswa di Kelas SMA Swasta Sinar Husni. Jurnal Pendidikan Fisika. 5(1), 32-41.

Salam, H., Setiawan, A., \& Hamidah, I. (2010). Pembelajaran berbasis virtual laboratory untuk meningkatkan penguasaan konsep pada materi listrik dinamis. Bandung: UPI.

Sardiman, S. (2007). Interaksi dan Motivasi Belajar Mengajar. Semarang: Unnes Press. 
Setyosari, P. (2016). Metode Penelitian Pendidikan Dan Pengembangan. Jakarta: Kencana.

Sugiyono. (2017). Statistika untuk Penelitian. Bandung :Alfabeta

Suprijono, A. (2012). Cooperative Learning Teori dan Aplikasi Paikem. Yogyakarta: Pustaka Pelajar.

Susanti, D F., Yenny, A., \& Suratmi, S. (2017). Penerapan Model Pembelajaran Giving Question Getting Answers terhadap Motivasi Belajar Peserta Didik pada Materi Sistem Koordinasi di SMA Negeri 10 Palembang. Seminar Nasional Pendidikan IPA. 1(1), 469-479.

Utami, U. (2014). Efektivitas Pemanfaatan Media Pembelajaran Animasi untuk Meningkatkan Motivasi dan Hasil Belajar Fisika Siswa Madrasah Aliyah Negeri Wonosobo. Prosiding Pertemuan IImiah XXVIII HFI Jateng \& DIY. 1(1), 334-337.

Wardani, A D., \& Supahar, S. (2017). Pengaruh Penerapan Model Pembelajara Giving Questin Getting Answers Menggunakan Media Audivisual terhadap Motivasi Belajar dan Hasil Belajar Peserta Didik Kelas X SMAN 2 Yogyakarta. Jurnal Pendidikan Fisika 6(6), 524-530.

Widiyanto, J. (2011). Penggunaan media berbasis komputer untuk meningkatkan prestasi belajar mahasiswa. Jurnal Pendidikan MIPA, 3(1), 42-46.

Widodo, S., Susanto, H., \& Yulianto, A. (2013). Pengaruh Pembelajaran Kooperatif Tipe Group Investigation Berbasis Eksperimen Inkuiri terhadap Motivasi Belajar Siswa. Unnes Physics Education Journal. 2(2), 13-18.

Yatim, R. (2009). Paradigma Baru Pembelajaran. Jakarta : Kencana Perdana Media Group.

Yunus, M., \& Kurniati, I. (2013). Pengaruh Model Pembelajaran Aktif Tipe Giving Question and Getting Answers terhadap Hasil Belajar Siswa Kelas $X$ SMA Negeri 1 Bajeng. Jurnal Chemica 14(1), 20-26. 